\title{
Fossil freshwater gastropods from northern Mexico - A case of a "silent" local extirpation, with the description of a new species
}

\author{
Alexander Czaja, Alan P. Covich, José Luis Estrada-Rodríguez, Ulises Romero-Méndez, Jorge Saenz-Mata, \\ Iris Gabriela Meza-Sánchez, Verónica Ávila-Rodríguez, Jorge Luis Becerra-López, \\ David Ramiro Aguillón-Gutiérrez, José Gamaliel Castañeda-Gaytán
}

\begin{abstract}
Alexander Czaja
José Luis Estrada-Rodríguez

Ulises Romero-Méndez

Jorge Saenz-Mata

Iris Gabriela Meza-Sánchez

Verónica Ávila-Rodríguez

Jorge Luis Becerra-López

David Ramiro Aguillón-Gutiérrez

José Gamaliel Gastañeda-Gaytán

drjlestrada@ujed.mx

Facultad de Ciencias Biológicas, Universidad Juárez del Estado de Durango, 35010 Gómez Palacio, Durango, Mexico.
\end{abstract}

\section{Alan P. Govich}

Institute of Ecology, Odum School of Ecology, University of Georgia, Athens, GA 306022202, USA.

BOL. SOC. GEOL. MEX. 2019

VOL. 71 NO. 3

P. $609-629$

http://dx.doi.org/10.18268/BSGM2019v7 ln3a2

Manuscript received: August 29, 2018.

Manuscript accepted: October 2, 2018.

\begin{abstract}
The decline of freshwater species diversity is a worldwide phenomenon but it is especially pronounced in arid regions such as in the Chihuahuan Desert of Coahuila and Durango, Northern Mexico. There are few historical data on the distribution but no data on extinctions of Mexican freshwater gastropods. In such cases, paleontological data can be very helpful and are often the only way to document past distributions and local extinction or extirpation events. This new paleoecological approach, called Conservation Paleobiology, can provide important perspectives in favor of conservation of recent analogue ecosystems. The study site contains subfossil (Late Holocene) deposits of the Laguna District, a small area in Coahuila and Durango. Here we describe a new species and report several new records of subfossil cochliopid, hydrobid, planorbid and neritid gastropods. Most of these species (and some genera) have not been known as fossil from Mexico and all of them disappeared in very recent times. Together with data from our former paleomalacological studies, we present herein an example of a "silent" local extirpation in northern Mexico that began in the Middle Holocene. This loss of species apparently increased rapidly in the second half of the 20th century. Of 32 species of freshwater snails present in the area of study through the Holocene only four $(12.5 \%)$ are still extant. At least $24(75.0 \%)$ of them disappeared from the area in the 20th century due to habitat loss caused by anthropogenic activities. The results show that especially hydrobiid species with small geographic ranges (local endemics are highly sensitive and vulnerable to such extirpation events. In this study area the extirpation of freshwater snails happened silently (unrecorded) while at the same time some two hundred kilometers farther north, one of the greatest recent hotspots of gastropods diversity in North America remained in the Cuatrociénegas Basin. The same imperilment that led to local extirpation in the area of study still threatens the freshwater snail communities of the Cuatrociénegas valley.
\end{abstract}

Keywords: Paleobiology, extirpation, gastropods, freshwater, loss of habitat.

\section{RESUMEN}

El declive de la diversidad de especies dulceacuícolas es un fenómeno mundial, pero es especialmente pronunciado en las regiones áridas como en el Desierto Chihuahuense de Coahuila y Durango, norte-centro de México. Existen pocos datos históricos sobre la distribución y ninguna información sobre extinciones de gasterópodos dulceacuícolas mexicanos. En tales casos, los datos paleontológicos pueden ser muy útiles y, a menudo, son la única forma de documentar las distribuciones pasadas y los eventos locales de extinción u extirpación. Este nuevo enfoque paleoecológico, llamado Paleobiología de Conservación, puede proporcionar perspectivas importantes para los esfuerzos de conservación de ecosistemas análogos recientes. El sitio de estudio contiene depósitos fósiles (Holoceno Tardío) del Distrito Laguna, un área pequeña en Coahuilay Durango. De estos depósitos fósiles describimos una nueva especie y reportamos varios registros nuevos de gasterópodos cochliópidos, hidróbidos, planórbidos y neritidos. La mayoría de estas especies y algunos géneros no se conocen como fósiles de México y todos ellos desaparecieron en tiempos muy recientes. En conjunto con datos de nuestros estudios paleomalacológicos anteriores, presentamos aqui un ejemplo de una extirpación local "silenciosa" en el norte de México la cual comenzó en el Holoceno Medio. Esta pérdida de especies aumentó rápidamente en la segunda mitad del siglo XX. De las 32 especies de caracoles dulceacuícolas presentes en el área de estudio durante el Holoceno, solo $4(12.5 \%)$ aún existen. Al menos 24 (75.0\%) de ellos desaparecieron del área en el siglo XX debido a la pérdida de hábitat causada por actividades antropogénicas. Nuestros resultados muestran que especialmente los hidróbidos con intervalos geográficos pequeños (especies endémicas locales) son altamente sensibles y vulnerables a tales acontecimientos de extirpación. La extirpación de los caracoles dulceacuícolas en el área de estudio ocurrió silenciosamente (sin registros), mientras que al mismo tiempo unos doscientos kilómetros más al norte, uno de los mayores focos de diversidad de gasterópodos en América del Norte permaneció en la cuenca de Cuatrociénegas. Las mismas amenazas que llevaron a la extirpación local en nuestra área de estudio aún amenazan a las comunidades de caracoles dulceacuícolas del valle de Cuatrociénegas.

Palabras clave: Paleobiología, extirpación, gasterópodos, dulceacuícolas, pérdida de hábitat. 


\section{Introduction}

The extinction of freshwater snails due to habitat loss is of wide interest and occurs especially among endemic species with restricted distributions, such as those in karst landscapes where lakes, groundwater-fed springs, and other habitats are threatened (e.g., Strong et al. 2008, Régnier et al. 2009). The distribution of extant freshwater gastropods of northern Mexico is poorly known and freshwater habitats are rapidly being altered by water diversions and dam construction. Only a portion of living species have been studied ecologically, anatomically or using molecular methods. Recent advances have focused mainly on systematics and biogeography of newly collected extant cochliopid and hydrobiid snails or species previously known only from shell morphology (Hershler et al., 2002, 2011 a, 201 lb, 2014a, 2014b). Without these data our systematic research affiliation of a part of the subfossil material would be much more difficult, or, as in some cases of shell convergences, almost impossible.

The study area is located in the central part of the Laguna District, a small karst region and it comprises the adjoining portions of western Coahuila and eastern Durango states, northern Mexico (Figure 1). The region, a large endorheic basin, was one of the largest paleo-lakes in Latin America during Late Pleistocene/Early Holocene (Butzer et al., 2008; Czaja et al., 2014b). Although this lake had become significantly smaller during the Holocene, large lakes were still present until the early 1900s (Ortega-Guerrero, 2003; Butzer et al., 2008). In the first half of the 20th century the region became an important center of agriculture and industry in Mexico. This economic process was accompanied by habitat perturbations such as damming and channelization of the two rivers, alteration of springs, and especially by excessive groundwater pumping. This aquifer depletion, described in detail by Wolfe (2013), finally eliminated the habitats provided by the remaining inland lakes and springs in the area of study.

From this semi-desert and karst region of south- west Coahuila and northeast Durango, we report subfossil shells belonging to cochliopid, hydrobiid, planorbid and neritid freshwater gastropod genera. The aim of the present study is to describe a new species, report new records and show their original biogeographic distribution prior to the loss of their habitats in recent times. To achieve that, we follow the "near-time" approach sensu Dietl and Flessa (2011) which utilizes the fossil record to understand the present-day conditions. In Mexico, this new interdisciplinary approach was applied so far only once (Figueroa-Rangel et al., 2012) but its potential has already been pointed out in detail by Guerrero-Arenas and Jiménez-Hidalgo (2015).

\section{Material and methods}

Shells of Juturnia gracilis n. sp., f. coahuilae (Taylor, 1966), Pseudotryonia pasajae (Hershler, Liu and Landye, 2011), Promenetus exacuous (Say, 1821) and Tryonia cf. seemani (Frauenfeld, 1863) were collected in present-day superficial sediments of dried-out springs near to the town of Viesca, Coahuila (Figure 1, site 2). All springs were still active in 1959 and dried out in the following years (Blásquez, 1959; Wolfe, 2013). Shells of Biomphalaria havanensis (Pfeiffer, 1839) were collected at west of Viesca springs in superficial sediments of a former wetland area of these springs (Figure 1, site 3). Shells of both species of Probythinella Thiele, 1929, Cochliopina riograndensis (Pilsbry and Ferriss, 1906) and Dilatata dilatata (Gould, 1841) were collected in fluviatile deposits of the Aguanaval River and in lacustrine sub-recent deposits of the paleo-lake Viesca (Figure 1, sites 5 and 4). A single shell of Vitta cf. usnea (Röding, 1798) was collected in a gray silt horizon with abundant planorbid snails of the former Paleo-Lake Irritila (Figure 1, site 1). These sediments with Vitta were not dated directly but the same horizon with abundant snails from a neighboring site was dated by Butzer et al. (2008) as Holocene playa deposits with radiometric calibrated ${ }^{14} \mathrm{C}$ ages between $3320 \pm 100$ at the top of the section and not older than $\sim 7130$ years BP at the bottom. 


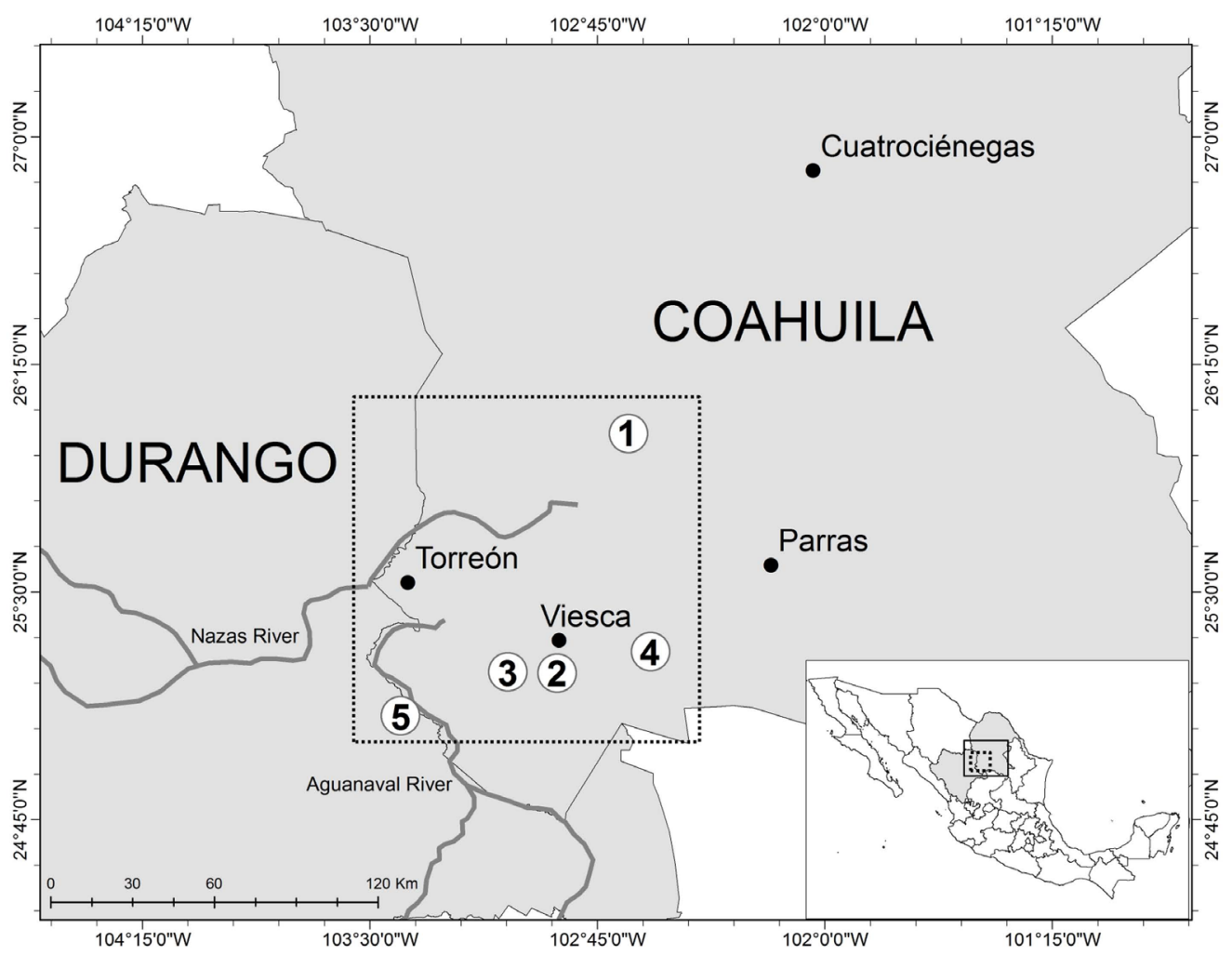

Figure 1 Map of the study area with localization of the sampled sites of the Laguna District of Coahuila and Durango. $1=$ Holocene playa deposits of the Paleo-Lake Irritila (Laguna Mayrán). 2 = Springs of Viesca. 3 = Former wetland area of the springs of Viesca. $4=$ Lacustrine sub-recent deposits of the Paleo-Lake Viesca. 5 = Sub-recent fluviatile deposits of the Aguanaval River. Dotted squares $=$ Area of study.

For a comparison of the subfossil material, empty shells of the extant species Pseudotryonia pasajae were collected in September 2016 from an unnamed spring in San Pedro de Ocuila, Durango, which is the type locality for this species. Empty shells of the extant Futurnia coahuilae from Poza Churince in Cuatrociénegas were collected in summer 2017 directly from sediments of this spring. Only the outflows of the dams of the Nazas and Aguanaval rivers and the small spring La Peña still contain permanent water in the area of study. Table 1 contains the coordinates of the localities that are monitored by the authors since 2009. These three sites were last sampled in summer 2017. The snails were hand collected from stones, sand and aquatic vegetation, $4 \mathrm{~kg}$ sediment per site was screened through sieves.

To visualize morphological shell differences between subfossil and living populations, a discriminant analysis was carried out. This was done using the software PAST (PAleontogical STatistics) v 3.14 (Hammer et al., 2001). This technique has frequently been used to differentiate closely similar shells of other hydrobiid and cochliopid gastropods (Czaja et al., 2017b). We used following shell morphometric dataset (excluding ratios): Total number of whorls, shell height, shell width, aperture height, aperture width, height of body whorl and width of body whorl. The mean, standard deviation and sample size are given in text (shell measurements).

Sediments of all localities were screened through two sieves with $0.5 \mathrm{~mm}$ and $0.3 \mathrm{~mm}$ mesh size. Some specimens (especially the apertures of the shells) were cleaned using hydrogen peroxide to remove sediments. All shells were photographed with a Zeiss AxioCam ERc5s-camera attached to a Zeiss Stemi 2000-C microscope. Morphometric variables of the shells were measured using the same microscope. Shell whorls were counted 
Table 1. The coordinates of three localities that still contain permanent water in the study area (outflows of the dams of the Nazas and Aguanaval rivers and the small spring La Peña).

\begin{tabular}{|c|c|c|c|}
\hline & Nazas River & Aguanaval River & La Peña spring \\
\hline Site 1 & $25^{\circ} 27^{\prime} 56^{\prime \prime} \mathrm{N}, 103^{\circ} 42^{\prime} 13^{\prime \prime} \mathrm{W}$ & $25^{\circ} 07^{\prime} 49^{\prime \prime} \mathrm{N}, 103^{\circ} 22^{\prime} 22^{\prime \prime} \mathrm{W}$ & $25^{\circ} 27^{\prime} 02^{\prime \prime} \mathrm{N}, 102^{\circ} 35^{\prime} 10^{\prime \prime} \mathrm{W}$ \\
\hline Site 2 & $25^{\circ} 27^{\prime} 55^{\prime \prime} \mathrm{N}, 103^{\circ} 42^{\prime} 12^{\prime \prime} \mathrm{W}$ & $25^{\circ} 13^{\prime} 14^{\prime \prime} \mathrm{N}, 103^{\circ} 26^{\prime} 58^{\prime \prime} \mathrm{W}$ & \\
\hline Site 3 & $25^{\circ} 39^{\prime} 30^{\prime \prime} \mathrm{N}, 103^{\circ} 22^{\prime} 51^{\prime \prime} \mathrm{W}$ & $25^{\circ} 01^{\prime} 36^{\prime \prime} \mathrm{N}, 103^{\circ} 16^{\prime} 09^{\prime \prime} \mathrm{W}$ & \\
\hline
\end{tabular}

according to the method of Pilsbry (1939). The material is housed in the Malacological Collection of the Faculty of Biological Science of the Juarez State University of Durango (UJED). Paratypes of the new species were deposited in the National Collection of Mollusks, National Autonomous University of Mexico (CNMO).

Abbreviations used in the text: $\mathrm{WN}$, total number of whorls; SH, shell height; SW, shell width; $\mathrm{AH}$, aperture height; AW, aperture width; HBW, height of body whorl; WBW, width of body whorl; sd, standard deviation; UJMC = University Juárez Malacological Collection.

\section{Results}

\subsection{SYSTEMATICS}

We emphasize that in the present paper we apply the morphological species concept widely used for paleobiological and paleontological studies. However, our morphospecies definitions are also based on insight from modern species concepts of living species that includes biogeographic considerations and population genetic aspects. A combination of neo- and paleobiological approach is mutually supportive in these determinations.

Superfamily Neritacea Lamarck, 1809

Family Neritidae Lamarck, 1809

Subfamily Neritininae Poey, 1852

Genus Vitta Mörch, 1852

Type species: Nerita virginea Linnaeus, 1758

Vitta cf. usnea (Röding, 1798)

(Figure 2a to 2e)
Description: Shell dextral, ovoid, with flat spire, height $7.82 \mathrm{~mm}$, width $6.79 \mathrm{~mm}$, with 3.00 whorls, whorls rapidly increasing in size, bodywhorl constitutes most of shell, surface smooth and porcellanous; sutures faintly impressed, with numerous microscopic axial growth lines and no spiral sculpturing, color pattern visible in the area of the sutures consisting of dark, wavy lines, which are closely spaced on a whitish background; aperture ovate, the outer lip is thickened and without teeth, parietal shelf straight with 12 (or 13?) irregular teeth (Figure 2e), teeth absent from the top and the bottom of the inner lip; numerous thin, parallel, brown to black axial lines as remains of the original color pattering (thin, parallel axial lines) visible only near the sutures (Figure $2 \mathrm{~d}$ ).

Shell Measurements: $\mathrm{SH}=7.82 \mathrm{~mm}, \mathrm{SW}=$ $6.79 \mathrm{~mm}, \mathrm{AH}=5.49 \mathrm{~mm}, \mathrm{AW}=3.67 \mathrm{~mm}, \mathrm{WN}$ $=3.00$.

Material Examined: 1 specimen (UJMC 360). Distribution: Florida to Texas, Mexico (gulf coast), West Indies (Eichhorst, 2016).

Remarks: Because it is a single specimen without color and pattern on the shell, our material can only be identified tentatively. Further, the specimen shows the teeth on the columellar lip much more defined than on modern Vitta usnea. The outer shell layer on the parietal shelf that leads up to these teeth probably has been broken off, exposing more of the teeth than is normally visible. The species is reported as Neritina reclivata (Say, 1822) in much of the recent literature, but we follow Eichhorst (2016) and placed this species in the genus Vitta because it lacks the characteristics 


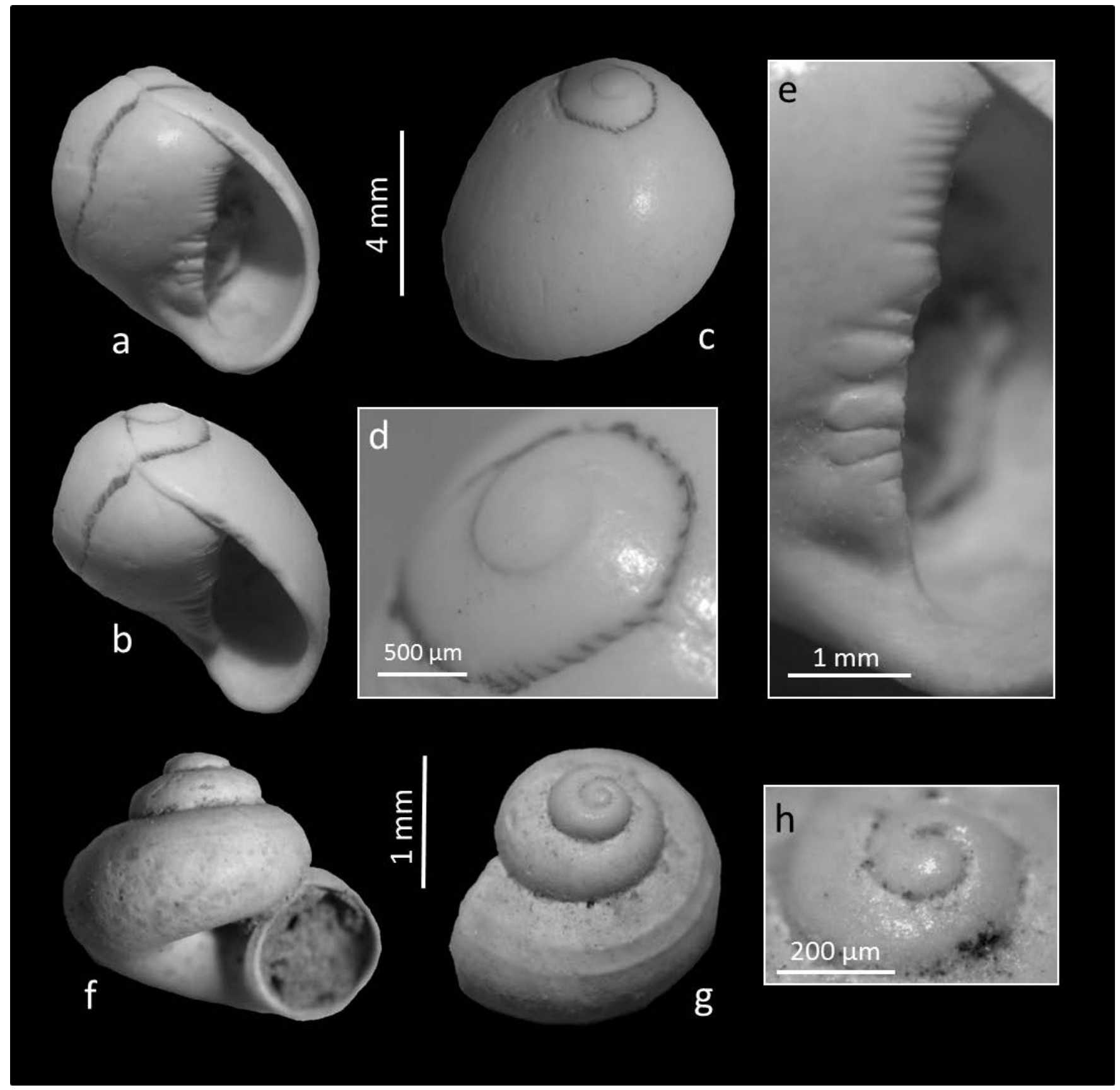

Figure 2 Vitta cf. usnea (Röding, 1798) and Cochliopina riograndensis (Pilsbry \& Ferriss, 1906). a-e) V. cf. usnea, UJMC 360. d) Black axial lines as remains of the original color pattering. e) Parietal shelf with irregular teeth. $f$-h) Cochliopina riograndensis. f) Specimen UJMC361a. g) Specimen UJMC 361b with cords on the bodywhorl. h) Specimen UJMC 361c, protoconch view. 
of Neritina. V. usnea, as it occurs in fresh/brackish water, on rocks, plant stems, or other hard surfaces and was found living in freshwater $160 \mathrm{~km}$ inland in Florida (Eichhorst, 2016). However, its Late Holocene presence in the study area almost $1000 \mathrm{~km}$ from the coast is notable. Although the species has a wide ecological range, occurrences in freshwater at long distances from the coast habitats are not known in its present-day distribution. Last record in the area: Middle/Late Holocene (radiometric calibrated ${ }^{14} \mathrm{C}$ ages between $3320 \pm$ 100 and 7130 years BP, Butzer et al., 2008).

Superfamily Truncatelloidea Gray, 1840

Family Cochliopidae Tryon, 1866

Genus Cochliopina Morrison, 1946

Type species: Cochliopa riograndensis Pilsbry \& Ferriss, 1906 (by original designation)

Cochliopina riograndensis (Pilsbry and Ferriss, 1906)

(Figure 2f to 2h)

Description: Shell small, broadly heliciform, height 1.39-2.02 mm, width 1.91-3.01 mm, openly umbilicate; apical whorl with pitted structure; teleoconch nearly smooth or frequently with spiral threads or (two) cords on the bodywhorls, one thread at the shoulder usually more prominent (Figure 2g); whorls moderately convex with deep sutures; the aperture is roundly ovate and angled adapically; peristome thin, inner lip partly fused to the penultimate whorl.

Shell Measurements: (mean, with sd in parentheses; $\mathrm{N}=10) \mathrm{SH}=1.65(0.28) \mathrm{mm}, \mathrm{SW}=2.41$ (0.31) $\mathrm{mm}, \mathrm{AH}=1.15(0.08) \mathrm{mm}, \mathrm{AW}=1.02$ (0.08) $\mathrm{mm}, \mathrm{WN}=3.40(0.21)$.

Material Examined: 10 specimens (UJMC 361a-j).

Distribution: Streams in Val Verde County, Texas and Northwest Mexico (Coahuila, San Luis Potosí, Tamaulipas) (Thompson, 2011).

Remarks: The subfossil shells from Durango and Coahuila correspond morphologically in all details to those from the type locality in Texas. Pilsbry and Ferriss (1906) noticed in the original description of $\mathrm{C}$. riograndensis a great similarity to shells of the genus Valvata (Müller, 1773), but they emphasized that species of the last genus have rounded apertures. According to Riedel (1993), the protoconchs of Valvata exhibit as well typical valvatid sculpture in form of numerous spiral lirae which are radially interconnected. Both shell features are not present in our material so we place the shells into the genus Cochliopina.

Genus futurnia Hershler, Liu and Stockwell, 2002 Type species: Durangonella coahuilae Taylor, 1966 (by original designation)

Juturnia gracilis Czaja, Covich, Estrada-Rodríguez and Romero-Méndez sp. nov.

(Figure 3a to 3g)

Diagnosis: Shell medium-sized, turriform, fragile, light tan or transparent, teleoconch of 8.00 to $11^{1 / 2}$ strongly convex whorls; teleoconch without sculpture, only with very fine and closely spaced growth lines; aperture ovate, inner and outer lip thin; umbilicus rimate to broadly open.

Description: Shell turriform, medium-sized, 4.82-7.32 mm shell length and 1.29-1.78 shell wide, with 8.00 to $11 \frac{1 / 2}{2}$ strongly convex and smooth whorls; teleoconch sculpture of closely spaced growth lines, from light tan to beige-white or transparent, in some specimens from light tan to brown periostracum preserved; protoconch of 0.7-1.0 whorl, smooth (Figure 3g); aperture ovate, inner lip thin to slightly thickened, broadly adnate to completely separate from parietal wall, outer lip thin or slightly thickened, the peristome is complete; umbilicus rimate to broadly open.

Shell Measurements: (mean, with sd in parentheses; $\mathrm{N}=15) \mathrm{SH}=5.75(0.61) \mathrm{mm}, \mathrm{SW}=1.49$ (0.13) $\mathrm{mm}, \mathrm{AH}=1.11(0.11) \mathrm{mm}, \mathrm{AW}=0.95$ (0.08) $\mathrm{mm}, \mathrm{HBW}=2.05(0.21) \mathrm{mm}, \mathrm{WBW}=1.29$ (0.12) $\mathrm{mm}, \mathrm{WN}=10.07$ (0.62).

Measurements of Holotype: $\mathrm{SH}=5.83 \mathrm{~mm}$, $\mathrm{SW}=1.47 \mathrm{~mm}, \mathrm{HBW}=1.97 \mathrm{~mm}, \mathrm{WBW}=1.30$ $\mathrm{mm}, \mathrm{AH}=1.07 \mathrm{~mm}, \mathrm{AW}=1.01 \mathrm{~mm}, \mathrm{WN}=10^{1 / 4}$. Differential Diagnosis: Of the four extant species of the genus futurnia, the new species only resembles f. coahuilae but differs clearly from this by having larger shells with considerably more whorls (7) coahuilae is possibly the described freshwater 
Boletín de la Sociedad Geológica Mexicana / 2019 / 61

615

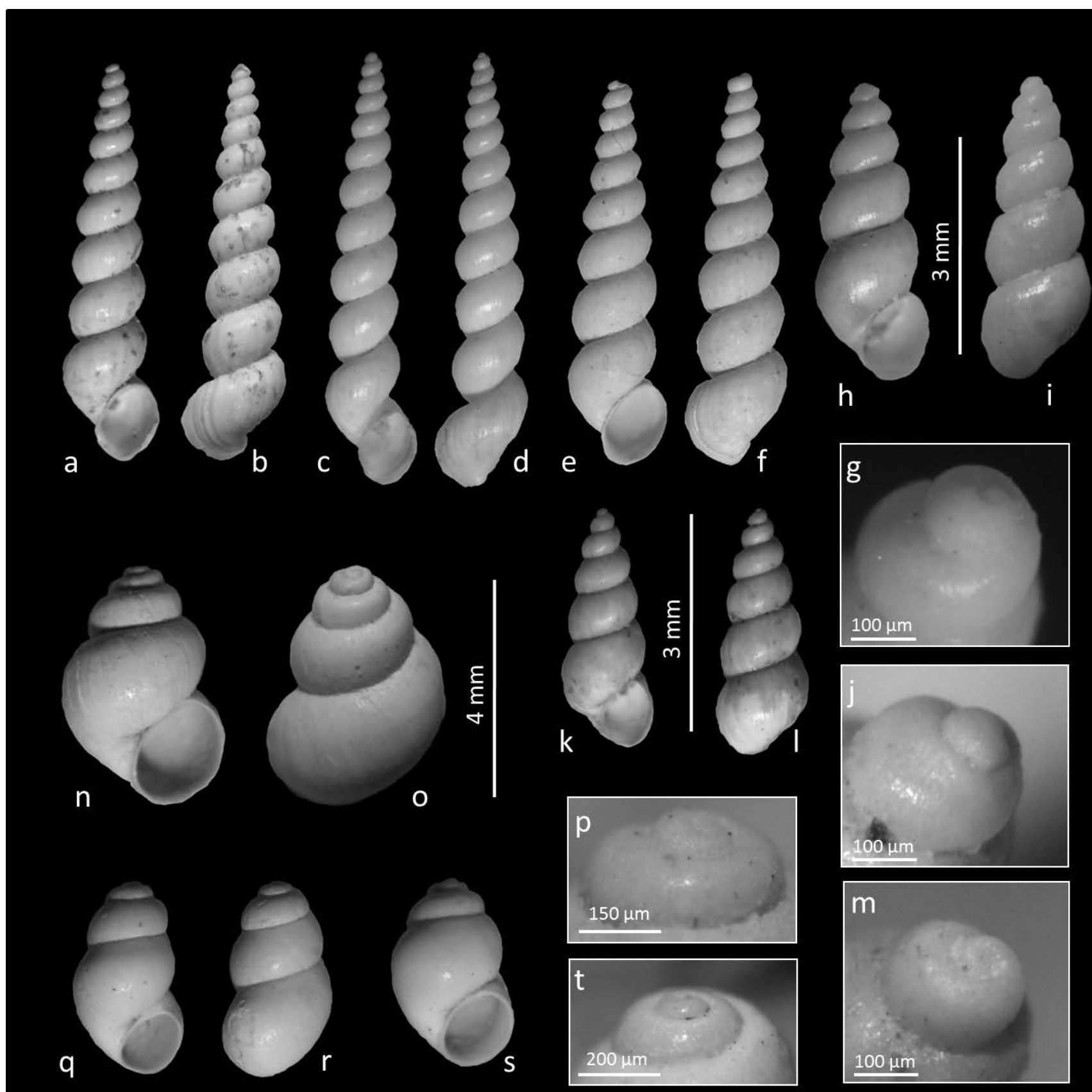

Figure 3 Juturnia gracilis new species, Juturnia coahuilae (Taylor, 1966) Hershler, Liu and Stockwell, Probythinella emarginata (Küster) and Probythinella protera Pilsbry. a, b, g) J. gracilis new species, Holotype, UJMC-362. g) Protoconch view. c, d) Paratype 1, UJMC-363. e, f) Paratype 2, UJMC-364. h-j) Juturnia coahuilae (Taylor, 1966) Hershler, Liu and Stockwell from spring Tunel 7, Viesca, Coahuila, Mexico, UJMC-366a. j) Protoconch view. k-m) J. coahuilae from Poza Churince, Cuatrociénegas, Coahuila, Mexico, a present-day specimen. m) Protoconch view. n-p) Probythinella emarginata, UJMC-367a. p) Protoconch view. q-t) Probythinella protera. q, r) Specimen UJMC-368a. s) Specimen UJMC-368b. t) Protoconch view, UJMC-368a. 
snail with most whorls in North America). Reliable diagnostic distinctions between these two species are as well the whorl height/whorl width ratio that is $0.21-0.29$ in 7 . gracilis $n$. sp. and $0.30-0.40$ in $\mathcal{F}$. coahuilae. As a result of this different ratio, $\mathcal{F}$. gracilis $\mathrm{n}$. sp. has a narrower general form than $\mathcal{F}$. coahuilae (Figure 3a to 3f). Also, the discriminant analysis (Figure 4), based on seven standard shell morphometric data, confirms that the subfossil shells of f. gracilis $\mathrm{n}$. sp. described herein are morphologically clearly distinct to shells of the extant endemic species from the Cuatrociénegas Basin. A combination between the detailed morphological description and morphometric based discriminant analyses were efficient in distinguishing among the recent and subfossil species.

Type Material: Holotype (Figures 3a, 3b, 3g), UJMC-362. Paratype 1 (Figures 3c, 3d), UJMC363, Paratype 2 (Figures 3e, 3f), UJMC-364.

(leg. Alexander Czaja and José Luis Estrada-Rodríguez, 25/vi/2016). All from type locality.
Type Locality: Mexico, Coahuila state, Viesca, Tunel 4 Spring $\left(25^{\circ} 20^{\prime} 20^{\prime} \mathrm{N}, 102^{\circ} 52^{\prime} 32^{\prime \prime} \mathrm{W}, 1099\right.$ $\mathrm{m}$ a.s.l.)

Stratum Typicum: Spring sediments (layer c. 5 $\mathrm{cm}$ below the present-day surface). Latest Holocene, sub-recent.

Other Material Examined: 12 specimens from the same locality (UJMC-365a-1).

Etymology: The species was named after the slender (lat. gracilis) general shape of its shells.

Distribution: 7. gracilis n. sp. is endemic to the Túnel 4 spring at Viesca, Coahuila, Mexico.

Remarks: Hershler et al. (2002) mentioned that shells of Futurnia broadly overlap in size, shape, and sculptural features with those of several other epigean cochliopines of southwestern North America such as Eremopyrgus, Littoridinops, Pseudotryonia and Tryonia. However, such narrow and turriform shells with numerous whorls (more than 7) are reported only from extant members of Juturnia and Tryonia. Both genera are difficult to separate

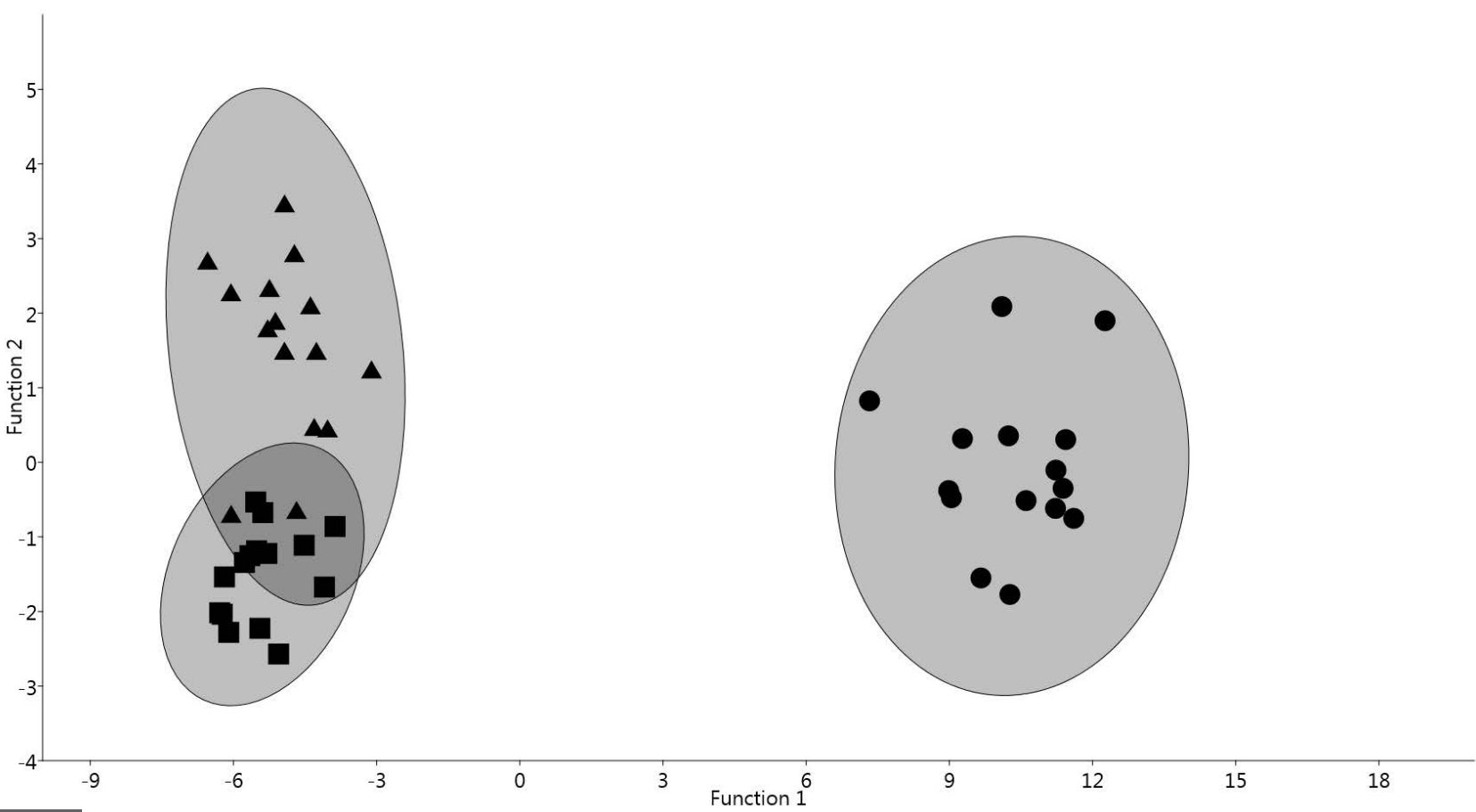

Figure 4 Graphic depiction of the discriminant analysis of morphometric variables of three populations of Juturnia. Circles = Juturnia gracilis new species, subfossil population from Spring Tunel 4, Viesca, Coahuila. Square $=$ J. coahuila (Taylor, 1966), a subfossil population from Spring Tunel 7, Viesca, Coahuila. Triangles = J. coahuila, a present-day population from Poza Churince, Cuatrociénegas, Coahuila. 
by shells and it seems that conchiologically only the well-developed growth lines on Futurnia shells is the unique useful differentiating feature between both genera. Of the three living species of the genus, 7 . gracilis $\mathrm{n}$. sp. closely resembles f. coahuilae (Taylor, 1966), an extant endemic species from the Cuatrociénegas Basin. In neighboring springs and spring-outflows in Viesca subfossil shells of $\mathcal{F}$. coahuilae are very common (see below). This geographical proximity and the similarity of the shell structure of $\mathcal{F}$. coahuilae and $\mathcal{F}$. gracilis n. sp. reflect undoubtedly a narrow phylogenic relationship between both species. We suppose that the subfossil f. gracilis n. sp. has evolved from $\mathcal{F}$. coahuilae in a separated spring (allopatric evolution) but a confirmation of this hypothesis requires further study of the vertical section of the spring deposits. According to Hershler et al. (2002), all four extant species of Juturnia are associated with saline environments. This can also be assumed for the former springs at Viesca since the groundwater, which once fed the springs with water, had (and has) high levels of salinity (Ortega-Guerrero, 2003).

\section{Juturnia coahuilae (D. W. Taylor, 1966)}

(Figure $3 \mathrm{~h}$ to $3 \mathrm{j}$ )

Durangonella coahuilae Taylor, 1966

Durangonella coahuilae Hershler, 1985, 81, fig. 32

Description: Morphologically, the subfossil shells are identical to those described by Taylor (1966) and Hershler (1985) from the type locality of this species.

Shell Measurements: (mean, with sd in parentheses; $\mathrm{N}=15) \mathrm{SH}=3.55(0.34), \mathrm{SW}=1.27(0.10)$ $\mathrm{mm}, \mathrm{AH}=0.95(0.13) \mathrm{mm}, \mathrm{AW}=0.76(0.04) \mathrm{mm}$, $\mathrm{HBW}=1.80(0.13) \mathrm{mm}, \mathrm{WBW}=1.19(0.09) \mathrm{mm}$, $\mathrm{WN}=6.12(0.21)$.

Material Examined: 15 specimens (UJMC 366a-o).

Distribution: The present-day species is endemic to the spring complex of the Cuatrociénegas basin, Coahuila.

Remarks: The subfossil $\mathcal{f}$. coahuilae from Viesca corresponds in its conchological features in almost all details to the recent species from Cuatrociénegas (Figures $3 \mathrm{~h}$ to $3 \mathrm{~m}$ ). The unique difference between the subfossil and extant species is the slightly narrower form of the subfossil species, which is also reflected in the discriminant analysis (Figure 4). However, these small morphological differences are, in view of the temporal and spatial distance of both populations, not surprising and we consider them within the variation of the extant species from Cuatrociénegas. The present record extends the (fossil) range of the genus futurnia c. $300 \mathrm{~km}$ to the south.

Genus Probythinella Thiele, 1928

Type species: Paludina emarginata Küster, 1852

Probythinella emarginata (Küster, 1852)

(Figure 3n to 3p)

Description: Shell small, sub-globose to narrow-conic or sub-cylindrical, height ranging from 3.24-4.69 mm, width $2.24-3.18 \mathrm{~mm}$; with $4^{3 / 4}-51 / 4$ whorls; whorls inflated, slightly convex to well rounded, sometimes slightly shouldered below suture, suture impressed; apex blunt or depressed, often tilted; body whorl rarely abruptly descending toward end of growth; teleoconch sculptured with strong, regularly spaced collabral striations extending from the suture to the base of whorl; first whorl sometimes planorboid, depressed; aperture ovate, sometimes weakly angled above, peristome usually narrowly adnate, or slightly separated, outer and inner lips thin; shell clear-white, some specimens transparent.

Shell Measurements: (mean, with sd in parentheses; $\mathrm{N}=10) \mathrm{SH}=4.11(0.63) \mathrm{mm}, \mathrm{SW}=2.75$ (0.41) $\mathrm{mm}, \mathrm{AH}=1.87(0.18) \mathrm{mm}, \mathrm{AW}=1.45$ $(0.20) \mathrm{mm}, \mathrm{HBW}=3.05(0.34) \mathrm{mm}, \mathrm{WBW}=2.43$ (0.30) $\mathrm{mm}, \mathrm{WN}=4.78(0.25)$.

Material Examined: 10 specimens (UJMC 367a-j).

Distribution: Eastern North America in lotic and lentic inland habitats throughout the Mississippi River basin; drainages of Great Lakes, Hudson Bay, and Mackenzie River to the north (Hershler, 1996). 
Remarks: The genus Probythinella includes only two extant species: P. emarginata and P. protera, both distributed along the eastern part of North America. Both species are well characterized by the extremely blunt apex of their shells (Figures 3p, $3 t$ ), a synapomorphy of this small group of North American Hydrobiidae (Hershler, 1996). Our records spread out the (fossil) range of $P$. emarginata c. $300 \mathrm{~km}$ to the south.

Probythinella protera Pilsbry, 1953

Type species: Amnicola emarginata Küster, 1852 (Figures 3q to 3t)

Description: Shell medium in size, ovate-conic to pupiform, height ranging from 2.54-2.92 $\mathrm{mm}$, width $1.51-1.82 \mathrm{~mm}$; with $4 \frac{1}{4}-4 \frac{1}{2}$ s slightly rounded whorls (accuracy to a $1 / 4$ whorl), first whorl almost planorbiform; umbilicus absent; apex blunt, sometimes depressed; aperture small, ovate and inclined approximately $40^{\circ}$ away from the coiling axes, inner lip thickened and adnate to the parietal wall, outer lip strongly thickened.

Shell Measurements: (mean, with sd in parentheses; $\mathrm{N}=10) \mathrm{SH}=2.69(0.13) \mathrm{mm}, \mathrm{SW}=1.69$ (0.10) $\mathrm{mm}, \mathrm{AH}=1.16(0.04) \mathrm{mm}, \mathrm{AW}=0.99$ $(0.07) \mathrm{mm}, \mathrm{HBW}=2.13(0.12) \mathrm{mm}, \mathrm{WBW}=1.64$ (0.10) $\mathrm{mm}, \mathrm{WN}=5.50(0.12)$.

Material Examined: 10 specimens (UJMC 368a-j).

Distribution: Endemic to United States, brackish waters along the eastern Gulf of Mexico coast (Hershler, 1996).

Remarks: Hershler (1996) mentioned that the recent distributions of both Probythinella species appear to be contiguous, but non-overlapping. That does not apply to our area, where both species occurred during the Holocene in lotic and lentic habitats as sympatric species. P. protera occurs in present-day only in coastal regions but our findings confirm that this species was, during the Holocene, also abundant in inland sites.

Genus Pseudotryonia Hershler, 2001

Type species: Tryonia alamosae Taylor, 1987 (by original designation)
Pseudotryonia pasajae Hershler, Liu and Landye, 2011

(Figure $5 \mathrm{a}$ to $5 \mathrm{~d}$ )

Pseudotryonia pasajae Hershler et al., 2011: 14, 16, figures. $2 \mathrm{E}-\mathrm{F}, \mathrm{I}-\mathrm{J}, \mathrm{M}-\mathrm{O}, 3 \mathrm{E}-\mathrm{H}, 4 \mathrm{D}-\mathrm{E}$.

Pseudotryonia pasajae Hershler et al., 2014: 59-60.

Description: Morphologically, the shells are identical to those described by Hershler et al. (2011b, p. 16) from the type locality of this species in Durango.

Shell Measurements: (mean, with sd in parentheses; $\mathrm{N}=11) \mathrm{SH}=2.21(0.50) \mathrm{mm}, \mathrm{SW}=1.38$ (0.22) $\mathrm{mm}, \mathrm{AH}=0.98(0.14) \mathrm{mm}, \mathrm{AW}=0.77$ $(0.08) \mathrm{mm}, \mathrm{HBW}=1.64(0.26) \mathrm{mm}, \mathrm{WBW}=1.23$ (0.19) $\mathrm{mm}, \mathrm{WN}=4.23(0.54)$.

Material Examined: 11 specimens (UJMG 369a-k).

Distribution: P. pasajae occurs living only in two springs northwest of Cuencamé de Ceniceros, Rio Nazas basin, Durango, Mexico (Hershler et al., 2014a).

Remarks: The results of the discriminant analysis did not reveal significant morphological differences among the subfossil shells from Viesca and shells of the endemic extant species $P$. pasajae from an unnamed spring at San Pedro de Ocuila, Durango, near the type locality (Figure 6). Almost all morphometric characters are within the phenotypic variation of the recent species. Small differences between the subfossil and extant populations remain only in the size of the shells, but these differences are even smaller than differences among the two known populations described by Hershler et al. (2014a) from the type locality and they are also visible in the discriminant analysis (Figure 6). The same author mentioned that P.pasajae shows sexual dimorphism in form of shells size differences, which is also observed in our material. Since all other shell characteristics of both forms are similar, we conclude that they may reflect the sexual dimorphism of the species. The subfossil shells were found in spring El Molino, Viesca, Coahuila, c. $100 \mathrm{~km} \mathrm{NE}$ from the type locality of this species in Durango. 
Genus Tryonia Stimpson, 1865

Type species: Tryonia clathrata Stimpson, 1865 (by original designation)

Tryonia cf. seemani (Frauenfeld, 1863)

(Figure $5 \mathrm{i}$ to $5 \mathrm{k}$ )

Hydrobia seemani Frauenfeld, 1863: 1025. Frauenfeld, 1865: 525, pl. 8.

Durangonella seemani (Morrison, 1945): Morrison, 1945, 19, pl. 3, Fig. 1

Description: Shell turriform, medium-sized, height $5.99 \mathrm{~mm}$, with $5^{1 / 2} 2$ rounded whorls. Teleoconch whorls highly convex, evenly rounded with strong impressed sutures. Sculpture of fine growth lines; aperture pyriform, parietal lip complete; umbilicus absent; periostracum tan.
Shell Measurements: $\mathrm{SH}=5.99 \mathrm{~mm}, \mathrm{SW}=$ $2.54 \mathrm{~mm}, \mathrm{AH}=2.09 \mathrm{~mm}, \mathrm{AW}=1.56 \mathrm{~mm}, \mathrm{HBW}$ $=3.64 \mathrm{~mm}, \mathrm{WBW}=2.25 \mathrm{~mm}, \mathrm{WN}=5^{1 / 2}$.

Material Examined: 1 specimen (UJMC-370).

Distribution: Endemic to a few springs near Durango City, Durango State (Hershler et al., 2011a).

Remarks: Our shell closely resembles shells from Durango described originally as Hydrobia seemani by Frauenfeld (1863). This species was later redescribed and placed as type species in the new erected genus Durangonella by Morrison (1945). Hershler et al. (2002) finally examined the rehydrated material and transferred this species to the genus Tryonia (Figure 5m). Our single high spired and strongly convex-whorled specimen is

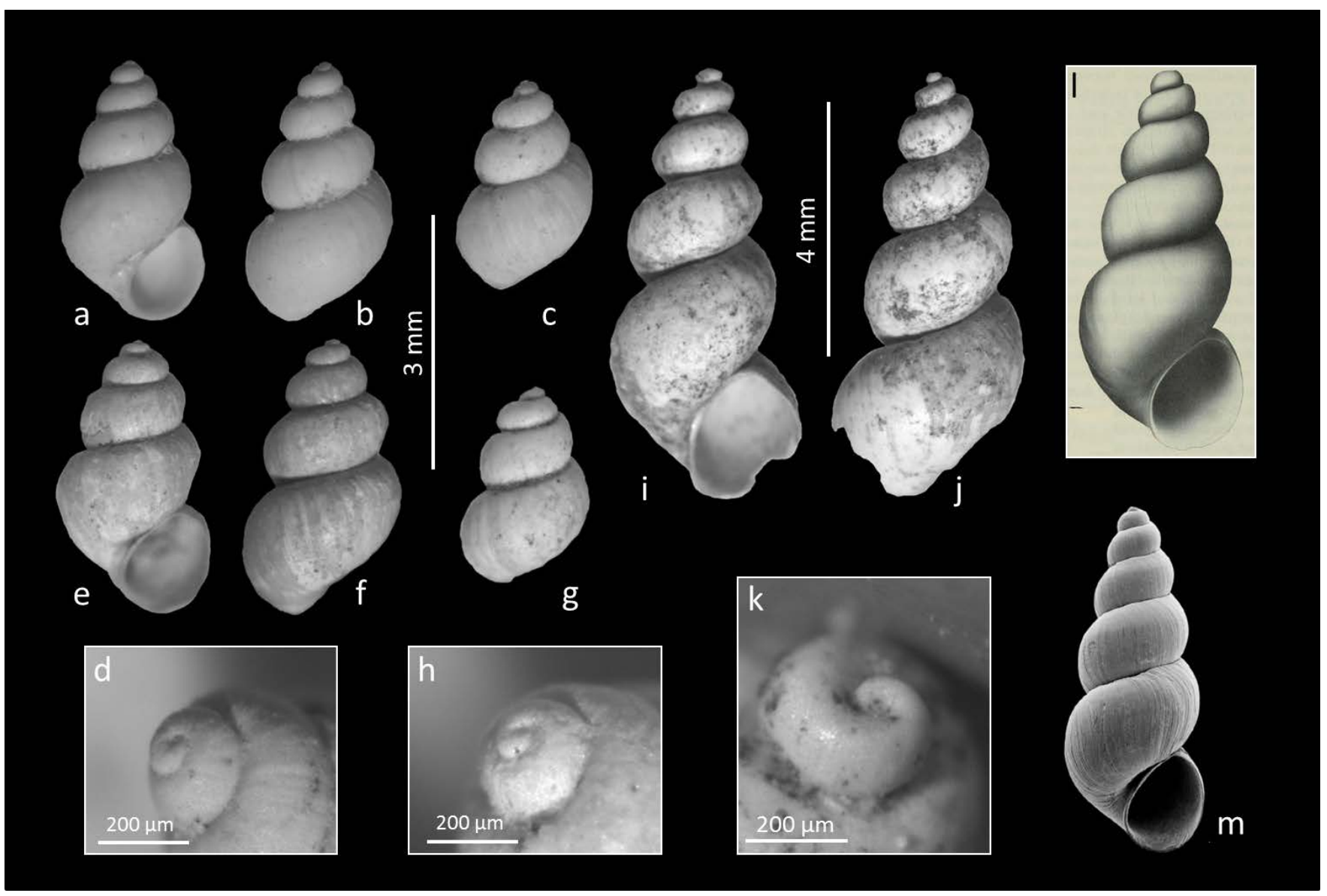

Figure 5 Pseudotryonia pasajae Hershler, Liu and Landye, 2011 and Tryonia cf. seemani (Frauenfeld, 1863). a-d) P. pasajae, specimen UJMC-369a. c) Male (?) specimen, UJMC-369b. d) Protoconch view, UJMC-369a. e-h) P. pasajae, a present-day specimen from San Pedro de Ocuila, Durango, Mexico. h) Protoconch view. i-m) T. seemani. i-k) T. cf. seemani, subfossil specimen from Viesca, Coahuila, Mexico, UJMC-370. k) Protoconch view. I) T. seemani from Durango, syntype (BMNH 20001099) illustrated by Hershler et al. (2002. Fig. 1b). m) T. seemani, a present-day specimen from an unnamed spring on west side of Nombre de Dios, Durango, Mexico (Hershler et al., 2011 a, Fig. 12c). 
morphologically near identical to the syntypes of the species from Durango illustrated by Hershler et al. (2002) (Figure 5l) and can therefore be considered as conspecific. A convergence is unlikely, however, since it is a single specimen we identify the subfossil shell from Viesca only tentatively. The single specimen was found in superficial sediments of the Juan Guerra Spring, Viesca.

Family Planorbidae H. and A. Adams, 1855

Genus Biomphalaria Preston, 1910

Type species: Biomphalaria smithii Preston, 1910

Biomphalaria havanensis (Pfeiffer, 1839)

(Figure $7 \mathrm{a}$ to $7 \mathrm{c}$ )

Biomphalaria obstructa (Morelet 1849): Test. Noviss.

I: 16.

Biomphalaria "temascalensis" Rangel-Ruiz 1987: 25-34; pl. 1.

Description: Shells medium to large (maximum diameter $13.25 \mathrm{~mm}$ ), flattened, discoidal; with 4 $3 / 4-53 / 4$ rounded whorls that increase moderately in diameter; spire flattened; sculpture of fine lines of growth pronounced on the bodywhorl, whorls separated by deep sutures; aperture ovate, the peristome is thin, without apertural lamellae.

Shell Measurements: (mean, with sd in parentheses; $\mathrm{N}=8) \mathrm{SH}=3.41(0.20) \mathrm{mm}, \mathrm{SW}$ (= shell diameter $)=12.10(0.83) \mathrm{mm}, \mathrm{WN}=5.19(0.35)$.

Material Examined: 8 specimens (UJMC 371a-h).

Distribution: The species occurs in southeastern USA, West Indies, Mexico and Central America. South American distribution remains to be determined (Thompson, 2011). According to Naranjo-García (2003), B. havanensis is the most common species of the genus in Mexico and inhabits mainly in areas along the Atlantic and Pacific coasts.

Remarks: The taxonomic history and systematics of the recent members of the genus Biomphalaria are long and confusing (DeJong et al. 2001). The subfossil shells from Viesca resemble shells of two extant species reported frequently from United States and Mexico: B. havanensis and B. obstructa.

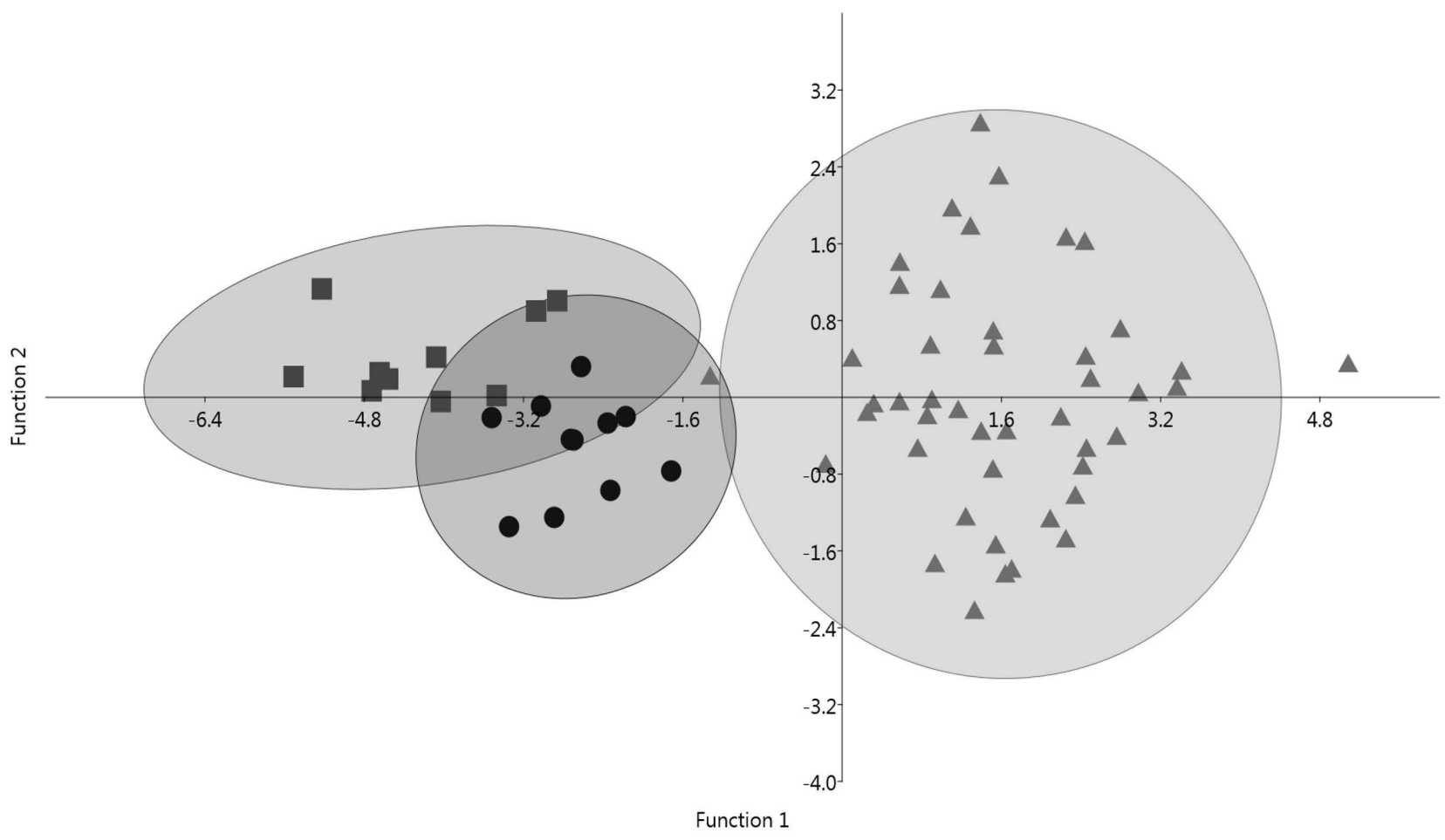

Figure 6 Graphic depiction of the discriminant analysis of morphometric variables of three populations of Pseudotryonia. Square $=\boldsymbol{P}$. pasajae, a subfossil population from Spring Tunel 4, Viesca, Coahuila. Circles $=P$. pasajae, a present-day population from an unnamed spring at San Pedro de Ocuila, Durango. Triangles = $P$. pasajae, a present-day population from el Tanque, Durango, type locality (data from Hershler et al., $2011 \mathrm{~b}$ ). 
Both species were considered for a long time as different species (DeJong et al., 2001; Thompson, 2011) but recent molecular studies show that $B$. obstructa (as well as B. tamascalensis Rangel-Ruiz from Oaxaca, Mexico) is a junior synonym of $B$. havanensis (Aguiar-Silva et al., 2014; Rosser et al., 2016).

Genus Dilatata Clessin, 1885

Type species: Planorbis dilatatus Gould, 1841

Dilatata dilatata (Gould, 1841)

(Figure $7 \mathrm{~d}$ to $7 \mathrm{f}$ )

Description: Shell small, ultradextral, flattened, discoidal (flat spiral), with few rapidly enlarging whorls; body whorl with less well-developed carina (keel), placed just above the center of the body; with 3 whorls (accuracy to a $1 / 4$ whorl), whorls rapidly increasing in size, sculpture of fine lines of growth; umbilicus deep; aperture large, expanded; lips slightly thickened.

Shell Measurements: Specimen 1: $\mathrm{SH}=1.63$ $\mathrm{mm}, \mathrm{SW}$ (= shell diameter) $=3.23 \mathrm{~mm}, \mathrm{AH}=$ $1.28 \mathrm{~mm}, \mathrm{AW}=1.59 \mathrm{~mm}, \mathrm{WN}=3$. Specimen 2: $\mathrm{SH}=1.22 \mathrm{~mm}, \mathrm{SW}$ (= shell diameter $)=2.68 \mathrm{~mm}$, $\mathrm{AH}=1.11 \mathrm{~mm}, \mathrm{AW}=1.31 \mathrm{~mm}, \mathrm{WN}=2.75$.

Material Examined: 2 specimens (UJMC 372a-b).

Distribution: Dilatata dilatata has a broad present-day distribution across United States from Florida and Texas to Canada (Baker, 1945; Burch, 1989). In Mexico in Zacatecas and Puebla (Albrecht et al., 2007; Thompson, 2011 as Micromenetus dilatatus).

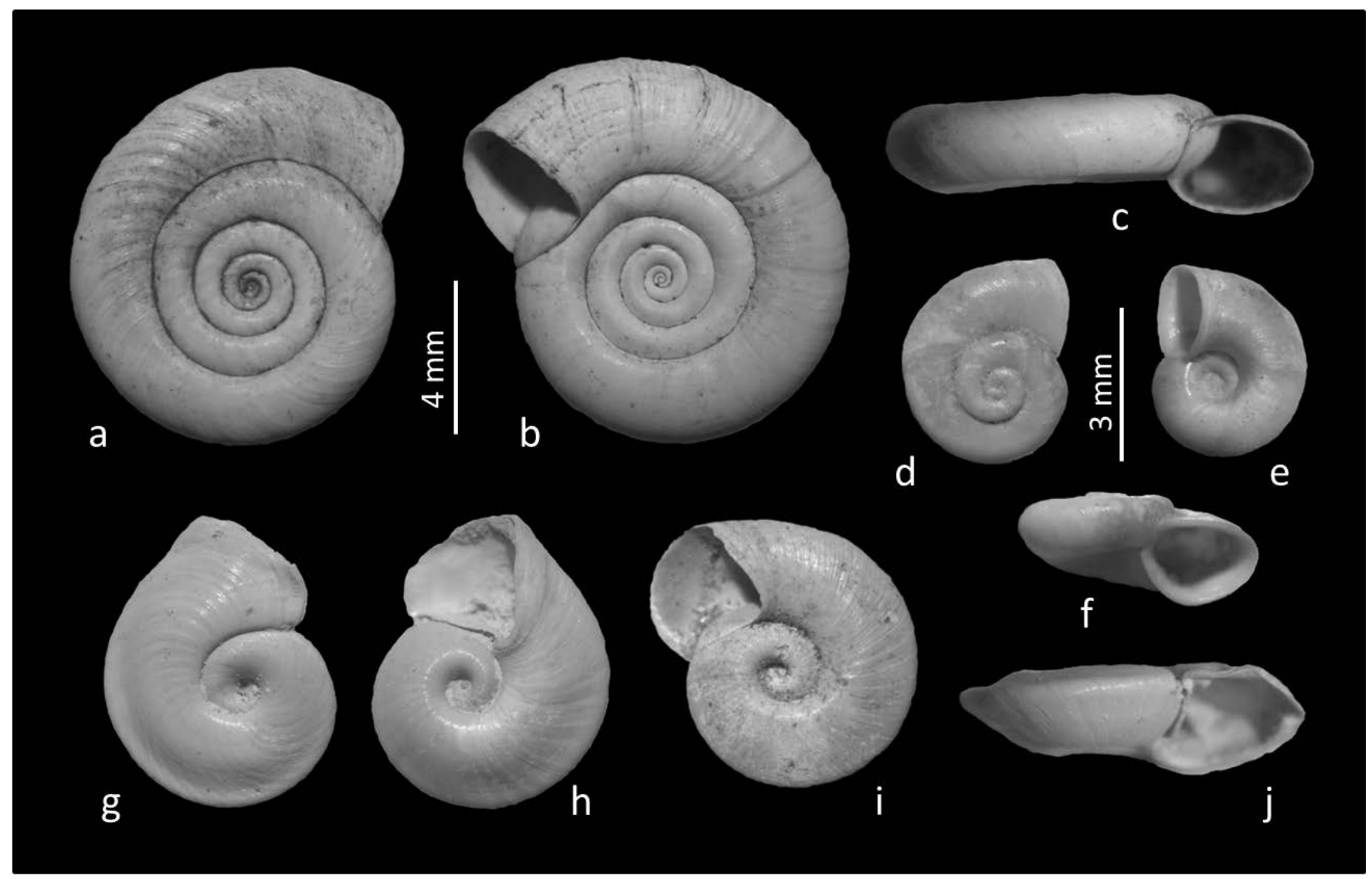

Figure 7 Biomphalaria havanensis (Pfeiffer, 1839), Dilatata dilatata (Gould, 1841) and Promenetus exacuous (Say, 1821). a-c) B. havanensis, fossil specimen UJMC-371a from a former wetland area of Viesca, Coahuila, Mexico. d-f) D. dilatata, subfossil specimen UJMC-372a from fluviatile deposits of the Aguanaval River, Durango, Mexico. g-j) $P$. exacuous subfossil specimens from spring el Molino, Viesca, Coahuila, Mexico. g, h, j) Specimen UJMC-373a. i) Specimen UJMC-373b. 
Remarks: The two subfossil specimens correspond in their shell morphology in all details to the recent material of this species. It is the first fossil record of this genus from Mexico.

Genus Promenetus Baker, 1935

Type species: Planorbis exacuous Say, 1821

Promenetus exacuous (Say, 1821)

(Figure $7 \mathrm{~g}$ to $7 \mathrm{j}$ )

Menetus exacuous (Say, 1821). Baker, 1928, Wisconsin Geol. Nat. History Survey Bull. 70, pt. 1, p. 361, pi. 23, fig. 1-5.

Promenetus exacuous exacuous (Say, 1821): Baker, 1945, Molluscan family Planorbidae, p. 182.

Promenetus exacuous megas (W.H. Dall, 1905): Baker, Molluscan family Planorbidae, p. 188.

Description: Shells medium (maximum diameter $8.43 \mathrm{~mm}$ ), flattened, discoidal (flat spiral), ultradextral, with carinate periphery (sharply keeled); keel close to or above the center of the body whorl; with $2^{1 / 4}-3 \frac{1}{2}$ whorls, whorls rapidly increasing in size; spire flattened; sculpture of fine lines of growth and fine spiral lines; umbilicus deep; aperture triangular or ovate, outer and inner lip thin to slightly thickened: some specimens with shell repair scars.

Shell Measurements: (mean, with sd in parentheses; $\mathrm{N}=10) \mathrm{SH}=1.91(0.07) \mathrm{mm}, \mathrm{SW}(=$ shell diameter $)=6.96(0.59) \mathrm{mm}, \mathrm{WN}=2.60(0.36)$.

Material Examined: 10 specimens (UJMC 373a-j).

Distribution: P. exacuous has a broad present-day distribution across Canada and United States (including Alaska) but does not reach Mexico.

Remarks: The prominent keel on the body whorl is the main characteristic of the shell of this species. Although there are no anatomical or radular differences, some authors such as Clarke (1981) and Prescott and Curteanu (2004) distinguish two subspecies of the Keeled Promenetus: P. e. exacuous and P. e. megas. However, we follow Burch (1989) and Turgeon et al. (1998) and do not recognize these subspecies because we considered that small differences in shell size alone are insufficient for a distinction. The southern limit of occurrence of living P. exacuous is Tarrant
County, Texas (Pratt, 1983), and our present record spread out the (fossil) range of the genus c. $1000 \mathrm{~km}$ to the south. It is the first fossil record of this genus from Mexico.

\section{Discussion}

There are few data about extinctions of freshwater gastropods in Mexico but Johnson et al. (2013) suggested that similar or greater extinctions likely occurred in Mexico and North America. The largest single modern extinction event of freshwater snails in North America took place in Coosa River, Alabama, United States, where within 50 years 33 species went extinct (Johnson et al., 2013). Our results from northern Mexico show a similar rapid loss of local freshwater snail species as in United States. This general decline of mollusks diversity began in the early to middle Holocene (Czaja et al., 2014a, 2014b), but then increased rapidly in the 20th century. The estimated times of local gastropod extirpation in the area (Table 2) are based on species described in the present study as well several other subfossil species reported recently from the same area (Czaja et al., 2014a, 2014b, 2015, 2017a, 2017b, 2017c). Of the 32 species present through the Holocene in Laguna District only four $(12.5 \%)$ are still living here. A quarter $(25 \%)$ is totally extinct, half of them $(50 \%)$ still live in Mexico and three species $(9 \%)$ occur only in United States and Canada. This means the loss of 88\% of the number of freshwater gastropod species in the area of study (Figure 8). The area is now a very dry region and belongs to the most populated regions in Mexico. Only the outflows of the dams of the Nazas and Aguanaval rivers and the small spring La Peña contain permanent waters. These sites are monitored by the authors since 2009 and contain only four gastropod species (Table 2).

Snails with small geographic ranges were more vulnerable to such extinction events than species with a wider distribution. Of the 28 species that disappeared from the area during the Holocene, 14 $(43 \%)$ were endemics (Table 2). Extirpation of all endemic species in this area apparently depended 
Table 2. List of gastropod species of the study area and estimated time prior of the local extirpation or extinction based on species described in the present study as well subfossil species reported previously from the same area. * Endemic species, bold = Species described in present paper.

\begin{tabular}{|c|c|c|c|c|}
\hline Family & Species & Holocene Records & $\begin{array}{l}\text { 20th Century } \\
\text { Records }\end{array}$ & \begin{tabular}{|c|} 
Present-day \\
Occurrence in are
\end{tabular} \\
\hline Assimineidae & Assiminea cienegensis* & $\mathrm{X}$ & $\mathrm{X}$ & \\
\hline Cochliopidae & Coahuilix hubbsi* & $\mathrm{X}$ & & \\
\hline Cochliopidae & Coahuilix landyei* & $\mathrm{X}$ & & \\
\hline Cochliopidae & Coahuilix parrasense* & $\mathrm{X}$ & $\mathrm{X}$ & \\
\hline Cochliopidae & Cochliopina riograndensis & $\mathrm{X}$ & $\mathrm{X}$ & \\
\hline Cochliopidae & Juturnia coahuilae* & $\mathrm{X}$ & $\mathrm{X}$ & \\
\hline Cochliopidae & Juturnia gracilis* & $\mathrm{X}$ & $\mathrm{X}$ & \\
\hline Cochliopidae & Mexipyrgus viescaensis* & $\mathrm{X}$ & $\mathrm{X}$ & \\
\hline Cochliopidae & Paludiscala thompsoni* & $\mathrm{X}$ & $\mathrm{X}$ & \\
\hline Cochliopidae & Phreatoceras taylori & $\mathrm{X}$ & $?$ & \\
\hline Cochliopidae & Tryonia cf. seemani & $\mathrm{X}$ & $\mathrm{X}$ & \\
\hline Cochliopidae & Tryonia hershleri* & $\mathrm{X}$ & & \\
\hline Cochliopidae & Tryonia paleocircumstriata* & $\mathrm{X}$ & $\mathrm{X}$ & \\
\hline Hydrobiidae & Cincinnatia integra & $\mathrm{X}$ & $\mathrm{X}$ & \\
\hline Hydrobiidae & Probythinella emarginata & $\mathrm{X}$ & $\mathrm{X}$ & \\
\hline Hydrobiidae & Probythinella protera & $\mathrm{X}$ & $\mathrm{X}$ & \\
\hline Hydrobiidae & Pseudotryonia pasajae* & $\mathrm{X}$ & $\mathrm{X}$ & \\
\hline Hydrobiidae & Pyrgulopsis manantiali* & $\mathrm{X}$ & & \\
\hline Hydrobiidae & Pyrgulopsis paleoacarinatus* & $\mathrm{X}$ & $\mathrm{X}$ & \\
\hline Hydrobiidae & Pyrgulopsis paleominckleyi* & $\mathrm{X}$ & $\mathrm{X}$ & \\
\hline Lymnaeidae & Galba obrussa & $\mathrm{X}$ & $\mathrm{X}$ & \\
\hline Neritidae & Vitta cf. usnea & $\mathrm{X}$ & & \\
\hline Physidae & Physella acuta & $\mathrm{X}$ & $\mathrm{X}$ & $\mathrm{X}$ \\
\hline Physidae & Physella pomilia & $\mathrm{X}$ & & \\
\hline Planorbidae & Biomphalaria havenensis & $\mathrm{X}$ & $\mathrm{X}$ & \\
\hline Planorbidae & Ferrissia californica & $\mathrm{X}$ & $\mathrm{X}$ & $\mathrm{X}$ \\
\hline Planorbidae & Gyraulus parvus & $\mathrm{X}$ & $\mathrm{X}$ & $\mathrm{X}$ \\
\hline Planorbidae & Hebetancylus excentricus & $\mathrm{X}$ & $\mathrm{X}$ & \\
\hline Planorbidae & Helisoma anceps & $\mathrm{X}$ & $\mathrm{X}$ & $\mathrm{X}$ \\
\hline Planorbidae & Dilatata dilatata & $\mathrm{X}$ & $\mathrm{X}$ & \\
\hline Planorbidae & Planorbella duryi & $\mathrm{X}$ & & \\
\hline Planorbidae & Promenetus exacuous & $\mathrm{X}$ & $\mathrm{X}$ & \\
\hline
\end{tabular}




\section{Decline in species richness}

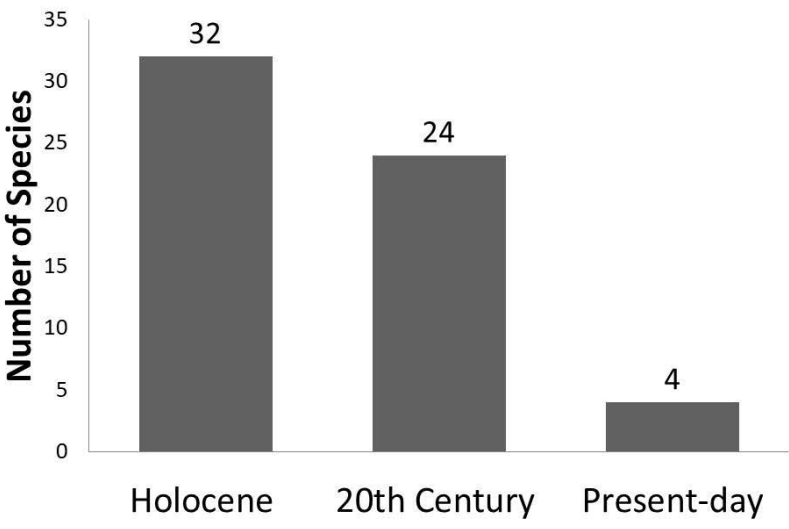

Figure 8 Decline in species richness of freshwater gastropods in the area of study during the Holocene.

on, among others factors, their limited dispersal ability, which is especially true for the phreatic species of Coahuilix, Paludiscala and Phreatoceras. Similar patterns of extinctions of endemics were also reported from other sites (Hershler et al., 2014b). However, also taxa with relatively wide recent distribution such as Promenetus, Dilatata, Cincinnatia, Biomphalaria and both species of Probythinella did not survive in this area. The genera Promenetus and Probythinella apparently disappeared completely from Mexico. Only Physella acuta (Draparnaud, 1805), Ferrissia californica (Rowell, 1863), Helisoma anceps (Menke, 1830) and Gyraulus parvus (Say, 1817) survived. Not surprisingly, all of them are known as very tolerant species with wide geographic ranges. It seems that of the 28 disappeared species only Planorbella duryi (Wetherby, 1879), Tryonia hershleri Czaja and Estrada-Rodriguez, 2015, Physella pomilia (Conrad, 1834) and Vitta usnea (Röding, 1798) disappeared from the area of study before human activities impacted the region.

The families most affected by the local extirpation were the Cochliopidae (12) and Hydrobiidae (7 species) and none of both currently have members in the area. These families belong to the most vulnerable freshwater gastropod families in North America, and they depend on groundwater inflows. Almost all endemic species of Cuatrociénegas also belong to these hydrobiid families.
The environmental impact was especially severe in the complex of 15 springs of Viesca in the central part of the Laguna District that dried up completely in the second half of the last century. The exact time of the drying is difficult to determine but in 1959 all 15 springs were still active (Blásquez, 1959). In 1961, some freshwater habitat must have existed around Viesca because type specimens of the Viesca Mud Turtle (Kinosternon hirtipes megacephalum Iverson) were collected (Legler and Vogt, 2013). Rhodin et al. (2011) reported 1970 as the approximate extinction date of the Viesca Mud Turtle and this could also be time of extirpation of the freshwater snails. That most snails from Viesca were still living in the 20th century is established by their common occurrence with Melanoides tuberculata (Müller, 1774) in the superficial sediments of the springs. This exotic species was introduced to North America in the 1930's (Rader et al., 2003).

The loss of aquatic habitats in Viesca occurred after decades of extensive overexploitation of groundwater pumping principally for irrigated agricultural production. In addition, the construction of two large dams further altered the groundwater hydrology. Wolfe (2013) has described how groundwater resources in Laguna District (especially at Viesca) were depleted from the 1920s to the 1960s. In this period, the number of water pumps increased from 12 to almost 3000 and, as a result, the groundwater level dropped by almost 100 meters. A few years later the lakes disappeared and also all 15 springs at Viesca had dried out (Figure 9). Similar local extinction events documented by Hershler et al. (2014b) from various sites in arid western North America coincide in time with the environment change in Laguna District. Also, there were especially hydrobid snails affected in these arid regions.

Assiminea cienegensis, 7. coahuilae, T. seemani, P. pasajae and Pyrgulopsis manantiali (Hershler, 1985) are still living near the area of study but all five species are now endemic to very restricted areas, including single springs. The subfossil records show that they had a wider distribution; hence, they are currently not only endemics but also relicts. 


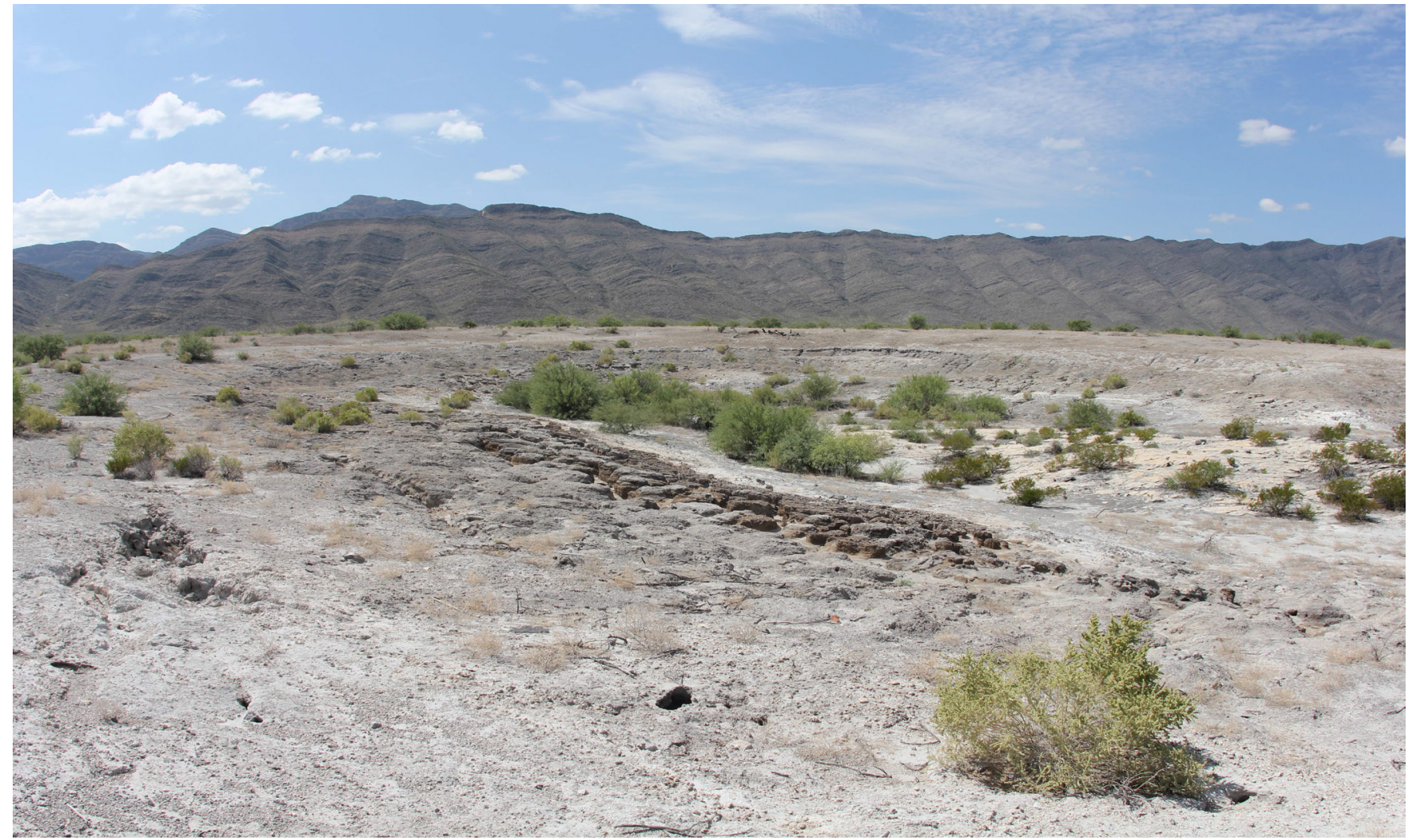

Figure 9 Spring Tunel 1 (Bilbao), Viesca, Coahuila, Mexico, that dried up in the second half of the last century (May 2018).

Although Promenetus exacuous and Probythinella emarginata are extirpated in Mexico, they have a widespread distribution in eastern United States and Canada and their populations are currently stable (Johnson et al., 2013). However, both species occur in semi-arid region of United States in only a very few sites. P. protera, a species common in late Holocene Rivers and lakes in the area of study, shows currently a very limited distribution in United States (Hershler, 1996). However, contrary to the more widespread $P$. emarginata, this species is not included in the IUGN Red List and does also not appear in the list of endangered freshwater species of Canada and the United States published by Johnson et al. (2013).

It cannot be ruled out that invasive species such as Melanoides tuberculata are at least partly responsible for the loss of gastropod diversity in the Laguna District. This species has long been suspected of displacing native populations (Thompson, 2004; Almeida et al., 2018). Although extirpation and invasion coincide temporally and spatially in the area of study, a causal relationship such as interspecific competition or increased parasitism is unclear. The current sampling demonstrates that the superficial sediments contain only a few specimens of Melanoides and its relative abundance never exceeds $0.1 \%$. Today, however, Melanoides is now by far the most abundant species in the localities that still contain water in the study area.

\section{Conclusions}

The local extirpation event described here from the Laguna District happened silently and unrecognized only some two hundred kilometers away from one of the currently greatest hotspots of gastropods diversity in North America, the Cuatrociénegas Basin. Unfortunately, the same human activities, especially groundwater pumping, that caused loss of aquatic habitat in the study area 
continue to endanger the ecosystems of Cuatrociénegas. One of the mottos of the Conservation Paleobiology concept created by Dietl and Flessa (2011) was "Using the Past to Manage for the Future". We hope that the large number of extirpated species reported here will strengthen the efforts to conserve threatened freshwater habitats in Mexico, especially in Cuatrociénegas basin.

\section{Acknowledgements}

We thank the Faculty of Biological Science of the Juárez University of the State of Durango for support us during this resaerch. We thank M.C. Juan Carlos Ibarra Flores of the Área de Protección de Flora y Fauna Cuatrociénegas for permission to collect soil samples of the Poza Churince in Cuatrociénegas. Dr. Thomas A. Neubauer (Justus Liebig University Giessen, Germany) and an anonymous reviewer provided numerous constructive comments.

\section{References}

Albrecht, C., Kuhn, K., Streit, B., 2007, A molecular phylogeny of Planorboidea (Gastropoda, Pulmonata): insights from enhanced taxon sampling: Zoologica Scripta, 36 (1), 27-39. https://doi. org/10.1111/j.1463-6409.2006.00258.x

Almeida, P.R.S., Nascimento Filho, S.L.,Viana, G.F.S., 2018, Effects of invasive species snails in continental aquatic bodies of Pernambucano semiarid: Acta Limnologica Brasiliensia, 30, 103. https://doi. org/10.1590/s2179-975x10616

Aguiar-Silva, C., C. Mendonça, P. da Cunha Kellis Pinheiro, S. Mesquita, Carvalho O., Caldeira, R., 2014, Evaluation and updating of the Medical Malacology Collection (Fiocruz-CMM) using molecular taxonomy: SpringerPlus, 3, 1-6. https://doi. org/10.1186/2193-1801-3-446

Baker, F.G., 1945, The molluscan family Planorbidae: University Illinois Press, Urbana xxxvi + pp. 530.
Blásquez, L.L., 1959, Hidrogeología de las regiones desérticas de México: Anales del Instituto de Geología, 15, pp. 172.

Burch, J. B., 1989, North American Freshwater Snails: Malacological Publications, Hamburg, Michigan, pp. 365.

Butzer, K.W., Abbott, J.T., Frederick, C.D., Lehman, P.H., Cordova, C.E., Oswald, J.F., 2008, Soil-geomorphology and "wet" cycles in the Holocene record of NorthCentral Mexico: Geomorphology, 101, 237-267. https://doi.org/10.1016/j. geomorph.2008.06.005

Clarke, A.H., 1981, The Freshwater Molluscs of Canada: National Museum of Natural Sciences, National Museums of Canada, Ottawa, Canada, pp. 446.

Czaja, A., Estrada-Rodríguez, J.L., RomeroMéndez, U., 2014a, Freshwater mollusks of the Valley of Sobaco, Coahuila, Northeastern Mexico - a subfossil ecosystem similar to Cuatrociénegas: Boletín de la Sociedad Geológica Mexicana, 66 (3), 459-469. https://doi.org/10.18268/ bsgm2014v66n3a4

Czaja, A., Palacios-Fest, M.R., Estrada-Rodríguez, J.L., Romero-Méndez, U., Alba-Ávila, J.A., 2014b, Inland Dunes mollusks fauna from the Paleolake Irritila in the Comarca Lagunera, Coahuila, Northern Mexico: Boletín de la Sociedad Geológica Mexicana, 66 (3), 541-551. https://doi.org/10.18268/ bsgm2014v66n3a9

Czaja, A., Estrada-Rodríguez, J.L., RomeroMéndez, U., 2015, A new species of the genus Mexipyrgus Taylor, 1966 (Caenogastropoda: Truncatelloidea: Cochliopidae) from late Holocene spring deposits in Viesca, Coahuila, Mexico: The Nautilus, 129, 163-168.

Czaja, A., Estrada-Rodríguez, J.L., RomeroMéndez, U. Orona-Espino, A., 2017a, Two new subfossil species of springsnails (Hydrobiidae: Pyrgulopsis) from north Mexico and their relation with extant species from Cuatrociénegas: Boletín de la Sociedad Geológica Mexicana, 69 (1), 199-208. https://doi.org/10.18268/ bsgm2017v69n1a9 
Czaja, A., Estrada-Rodríguez, J.L., RomeroMéndez,U.,Estrada-Arellano,J.R.,GonzálezZamora, A., 2017b, Primer registro fósil del gasterópodo Cincinnatia (Hydrobiidae: Nymphophilinae) en México: Revista Mexicana de Biodiversidad, 88, 912-917. https://doi.org/10.1016/j.rmb.2017.10.025

Czaja, A., Estrada-Rodríguez, J.L., RomeroMéndez, U., Ávila-Rodríguez, V., MezaSánchez, I.G., Govich, A.P., 2017c, New species and records of phreatic snails (Caenogastropoda: Cochliopidae) from the Holocene of Coahuila, Mexico: Archiv für Molluskenkunde, 146 (2), 227-232. https:// doi.org/10.1127/arch.moll/146/227-232

DeJong, R.J., Morgan, J.A.T., Paraense, W.L., Pointier, J.P., Amarista, M., Ayeh-Kumi, P.F.K. et. al. 2001, Evolutionary relationships and biogeography of Biomphalaria (Gastropoda: Planorbidae) with implications regarding its role as host of the human bloodfluke, Schistosoma mansoni: Molecular Biology and Evolution, 18 (12), 2225-2239. https://doi.org/10.1093/oxfordjournals. molbev.a003769

Dietl, G.P. and Flessa, K.W., 2011, Conservation paleobiology: putting the dead to work: Trends in Ecology and Evolution, 26 (1), 30-37. https://doi.org/10.1016/j. tree.2010.09.010

Eichhorst, T.E., 2016, Neritidae of the world. Vol. 2. Harxheim: Conchbooks, 696-1366.

Figueroa-Rangel, B.L., Willis, K.J. and Olvera-Vargas, M., 2012, Late-Holocene successional dynamics in a transitional forest of west-central Mexico: The Holocene, 22(2), 143-153. https://doi. org/10.1177/0959683611414929

Frauenfeld, G.R. von, 1863, Vorläufige Aufzählung der Arten der Gattungen Hydrobia Htm. und Amnicola Gld. Hldm. in der kaiserlichen und in Cuming's Sammlung: Verhandlungen der Kaiserlich-Königlichen Zoologischbotanischen Gesellschaft in Wien, 13,1017-1032.
Frauenfeld, G.R. von, 1865, Zoologische Miscellen: Verhandlungen der Kaiserlich-Königlichen Zoologisch-botanischen Gesellschaft in Wien, 15, 525-536.

Guerrero-Arenas, R., Jiménez-Hidalgo, E., 2015, El registro fósil y la conservación de la biodiversidad actual: Ciencia y Mar, 23, $67-75$.

Hammer, R., Harper, D.A.T., Ryan P.D., 2001, PAST: Paleontological statistics software package for education and data analysis. http://palaeo-electronica.org/2001_1/ past/issue1_01.htm. [Accessed 23. July. 2019].

Hershler, R., 1985, Systematic revision of the Hydrobiidae (Gastropoda: Rissoacea) of the Cuatro Cienegas Basin, Coahuila, Mexico: Malacologia, 26 (1-2), 31-123.

Hershler, R., 1996, Review of the North American aquatic snail genus Probythinella (Rissooidea: Hydrobiidae): Invertebrate Biology, 115 (2), 120-144. https://doi.org/10.2307/3227043

Hershler, R., 2001, Systematics of the North and Central American aquatic snail genus Tryonia (Rissooidea: Hydrobiidae): Smithsonian Contributions to Zoology, 612, 1-53. https:// doi.org/10.5479/si.00810282.612

Hershler, R., Liu, H.-P., Stockwell, C.A., 2002, A new genus and species of aquatic gastropods (Rissooidea: Hydrobiidae) from the North American Southwest: phylogenetic relationships and biogeography: Proceedings of the Biological Society of Washington, 115 (1), 171-188.

Hershler, R., Liu, H.-P., Landye, J.J., 2011 a, New species and records of springsnails (Caenogastropoda: Cochliopidae: Tryonia) from the Chihuahuan Desert (Mexico and United States), an imperiled biodiversity hotspot: Zootaxa, 3001, 1-32. https://doi. org/10.11646/zootaxa.3001.1.1

Hershler, R., Liu, H.-P., Landye, J.J., 2011b, Two new genera and four new species of freshwater cochliopid gastropods (Rissooidea) from northeastern Mexico: Journal of Molluscan Studies, 77 (1), 8-23. https://doi. org/10.1093/mollus/eyq033 
Hershler, R., Landye, J.J., Liu, H.-P., De la Maza-Benignos, M., Ornelas, P., Carson E.W., 2014a, New species and records of Chihuahuan Desert springsnails, with a new combination for Tryonia brunei: Western North American Naturalist, 74 (1), 47-65. https://doi.org/10.3398/064.074.0105

Hershler, R., Liu, H.-P., Howard, J., 2014b, Springsnails: a new conservation focus in western North America. BioScience, 64 (8), 693-700. https://doi.org/10.1093/biosci/ biu 100

Johnson, P.D., Bogan, A.E., Brown, K.M., Burkhead, N.M., Cordeiro, J.R., Garner, J.T., Hartfield, P.D., Lepitzki, D.A.W., Mackie, G.L., Pip, E., Tarpley, T.A., Tiemann, J.S., Whelan, N.V., Strong, E.E., 2013, Conservation status of freshwater gastropods of Canada and the United States: Fisheries, 38 (6), 247-282. https://doi.org/10.1080/0 3632415.2013 .785396

Legler, J.M., Vogt, R.C., 2013, The Turtles of Mexico: Land and Freshwater Forms: University of California Press, 416 pp.

Morrison, J.P.E., 1945, Durangonella, a new hydrobiine genus from Mexico, with threenew species: The Nautilus, 59, 18-23.

Naranjo-García, E., 2003, Moluscos continentales de México: dulceacuícolas: Revista de Biología Tropical, 51 (3), 495-505.

Ortega-Guerrero, A., 2003, Origin and geochemical evolution of groundwater in a closed-basin clayey aquitard, Northern Mexico: Journal of Hydrology, 284 (1), 26-44. https://doi.org/10.1016/ s0022-1694(03)00239-7

Pilsbry, H.A., 1939, Land Mollusca of North America: Academy of Natural Sciences of Philadelphia, Monograph 3, pp. 547.

Pilsbry, H.A., Ferriss, J.H., 1906, Mollusca of the southwestern states, II: Proceedings of the Academy of Natural Sciences of Philadelphia, 58, 123-175.
Pratt, W.L., 1983, Living Promenetus exacuosus (Pulmonata: Planorbidae) from North Central Texas: The Nautilus, 97 (2), 73-74.

Prescott, D.R.C., Curteanu, M.M., 2004, Survey of Aquatic Gastropods in the Central Parkland Subregion of Alberta: Alberta Sustainable Resource Development, Fish and Wildlife Division, Alberta Species at Risk Report No. 92, Edmonton, AB, pp. 50. https://doi.org/10.5962/bhl.title.1 14093

Rader, R.B., Belk, M.C., Keleher, M.J., 2003, The introduction of an invasive snail (Melanoides tuberculata) to spring ecosystems of the Bonneville Basin, Utah:Journal of Freshwater Ecology, 18 (4), 647-657. https://doi.org/10 $.1080 / 02705060.2003 .9664007$

Régnier, C., Fontaine, B., Bouchet. P., 2009, Not knowing, not recording, not listing: numerous unnoticed mollusk extinctions: Conservation Biology, 23 (5), 1214-1221. https://doi. org/10.1111/j.1523-1739.2009.01245.x

Rhodin, A.G.J., Walde, A.D., Horne, B.D., van Dijk, P.P., Blank, T., Hudson, R., 2011, Turtles in Trouble: The World's 25+ Most Endangered Tortoises and Freshwater Turtles, Lunenburg, MA: IUGN/SSG Tortoise and Freshwater Turtle Specialist Group, Turtle Conservation Fund, Turtle Survival Alliance, Turtle Conservancy, Chelonian Research Foundation, Conservation International, Wildlife Conservation Society, and San Diego Zoo Global, pp. 54.

Riedel, F., 1993, Early ontogenetic shell formation in some freshwater gastropods and taxonomic implications of the protoconch: Limnologica, 23, 349-368.

Rosser, T.G., Alberson, N.R., Khoo, L.H., Woodyard, E.T., Wise, D.J., Pote, L.M. and Griffin, M.J., 2016, Biomphalaria havanensis is a Natural First Intermediate Host for the Trematode Bolbophorus damnificus in Commercial Catfish Production in Mississippi: North American Journal of Aquaculture, 78 (3), 189-192. https://doi.or g/10.1080/15222055.2016.1150922 
Strong, E.E., Gargominy, O., Ponder, W.F., Bouchet, P., 2008, Global diversity of gastropods (Gastropoda; Mollusca) in freshwater: Hydrobiologia, 595 (1), 149-166. https:// doi.org/10.1007/s10750-007-9012-6

Taylor, D.W., 1966, A remarkable snail fauna from Coahuila, Mexico: The Veliger, 9, 152-228.

Thompson, F.G., 2004, An identification manualfor the freshwater snails of Florida http:/ / www.flmnh.ufl.edu/malacology/flsnail/snails1.htm [Accesed 14 May 2018].

Thompson, F.G., 2011, The land and freshwater snails of Mexico and Central America: Bulletin of the Florida Museum of Natural History, 50, 1-299.
Turgeon, D.D., Quinn, J.F. Jr., Bogan, A.E., Coan, E.V., Hochberg, F.G., Lyons, W.G., Mikkelsen, P.M., Neves, R.J., Roper, C.F.E., Rosenberg, G., Roth, B, Scheltema, A., Thompson, F.G., Vecchione, M., Williams, J.D., 1998, Common and scientific names of aquatic invertebrates from the Unites States and Canada: mollusks, 2nd edition: American Fisheries Society, Special Publication 26. American Fisheries Society, Bethesda, Maryland, pp. 526.

Wolfe, M., 2013, The historical dynamics of Mexico's groundwater crisis in $\mathrm{La}$ Laguna: Knowledge, resources, and profit, 1930s-1960s: Mexican Studies/Estudios Mexicanos, 29 (1), 3-35. https://doi. org/10.1525/msem.2013.29.1.3 